\title{
EXPORT POTENTIAL OF UKRAINIAN AGRO-INDUSTRIAL COMPLEX: FACTORS OF FORMATION AND EVALUATION
}

\author{
Tetiana Melnyk ${ }^{1}$, Yuliia Tunitska², Anna Liubyma ${ }^{3}$
}

\begin{abstract}
With the intensification of international integration processes, export potential is the most important factor in the economic growth of states and a condition for equal accession to the world economy. The purpose of the study is to identify the factors of formation and implementation of the export potential of the agroindustrial complex of Ukraine, its evaluation, the definition of the place of Ukrainian products on world food markets. Methodology. To achieve the designated objectives, a comprehensive approach was used, which included the calculation of indicators of export potential of Ukrainian agro-industrial complex in international trade with the countries of the world and in comparison with major trading partners through the dynamics and structure of foreign trade, export value per capita, export quota, export share of goods in their production, net export potential coefficient; the ratio of the export quota to the population; the country's export efficiency ratio; the country's participation in the international division of labour; the indicator of comparative (relative) advantages. Research results. It was established that the export potential of Ukrainian agro-industrial complex is formed under the influence of stimulating and restraining factors. During the period under review (2010-2020) high rates of development of foreign trade in agri-food products of Ukraine were revealed, especially with the countries of Asia, Europe and Africa. However, there are also negative trends: strengthening the export potential of the complex at the expense of raw materials and semi-finished products and at the expense of losing positions in the world market of Ukrainian products with high added value; unjustified priority to stimulate export of agricultural products, which confirms the low level of export efficiency, despite the significant activity of Ukraine in the world market compared to partner countries; low level of export potential of Ukrainian agroindustrial complex in comparison with EU countries as a result of technological backwardness of the producer; small list of export agro-industrial commodity groups with sustainable comparative advantages and their low technology in relation to countries of all world regions indicates the low level of development of agriculture and the economy as a whole. In this regard, there is a need for structural reforms in the agro-industrial complex of Ukraine, strengthening institutional support for the production and export of food products, which contain a high level of added value. Practical implications. The main theoretical provisions and conclusions formulated by the authors can serve as a methodological basis for improving the export strategies of various sectors of the economy. Value/originality. The proposed results can be used to justify the mechanism of formation of the export potential of the agro-industrial complex of Ukraine on the basis of increasing the production of goods with high added value.
\end{abstract}

Key words: export potential, foreign trade, agro-industrial complex, globalization, integration.

JEL Classifications: F14, F15, F18, F55

\footnotetext{
Corresponding author:

${ }^{1}$ Kyiv National University of Trade and Economics, Ukraine.

E-mail: t.melnyk@knute.edu.ua

ORCID: https://orcid.org/0000-0002-3839-6018

ResearcherID: https://publons.com/researcher/1673478/tetiana-melnyk/

${ }^{2}$ Independent researcher, Ukraine.

E-mail: juliar_2006@ukr.net

ORCID: https: //orcid.org/0000-0002-8501-1299

ResearcherID: https://publons.com/researcher/2226436/julia-mykolaivna-tunitska/

${ }^{3}$ Kyiv National University of Trade and Economics, Ukraine.

E-mail: a.lyubyma@knute.edu.ua

ORCID: https://orcid.org/0000-0002-4871-9212
} 


\section{Introduction}

In a globalized world economy, the efficiency of the economic complex of the state and the success of its participation in international integration processes is directly proportional to the level of export development, which indicates the importance of the issues of this article. Historically, the key to achieving the leading position of Ukraine in the international arena is a powerful agro-industrial complex (the share of agricultural exports in the country's GDP in 2020 was 14\%) (State Statistics Service of Ukraine, 2020), which in the context of the changing structure of the world population, aggravation of the global food problem and the intensified search for ways to solve it, provides both domestic and foreign markets with food. Favorable geographical location, natural and climatic conditions, as well as exceptional land and human resources contributed to the formation of the export potential of the agro-industrial complex of Ukraine (hereinafter the AIC) - the ability of the agrarian sector to produce the necessary amount of goods competitive in foreign markets, which will contribute to the economic growth of the country (Polkovnichenko, Rosokhach, 2016). Despite periodic losses due to falling world prices, total exports continue to grow every year, replenishing the budget (45\% of Ukraine's total export revenues in 2020) (State Statistics Service of Ukraine, 2020) and investing in the modernization of the agricultural sector.

The structure of Ukrainian food exports consists mainly of agricultural raw materials without a significant increase in the volume of processed products, which is a consequence of imperfect mechanisms of state regulation of the development of agriculture and foreign economic relations. The situation is aggravated by crises related to the loss of the main market due to the military-political confrontation and the introduction of quarantine measures due to the COVID-19 pandemic. Ukrainian exporters, working in harsh competitive conditions, are forced to adapt to the global challenges and bring food production in line with modern global quality standards, mostly with limited financial resources and insufficient state support compared to developed countries.

Consequently, in the current realities of volatile external environment, the reorientation of commodity and geographic structure of food exports on the basis of a comprehensive approach to monitoring the export potential of the Ukrainian agro-industrial complex by assessing its trends, identifying national conditions and factors of formation, determining the comparative advantages of Ukrainian products on world markets, which indicates the relevance of the chosen topic of research.

\section{Literature review}

Ukrainian scientists mainly study the general trends and prospects of development of exports of the main types of agricultural products of Ukraine. Thus, based on a thorough analysis of the export-import balance of Ukraine's agro-industrial complex, it was proposed to solve the key problems of agriculture and food industry by supporting the network interaction of enterprises (Izhevskyi, 2018). A list of regions and specific countries where Ukrainian agricultural products are in greatest demand was determined, as well as the ranking positions of Ukraine on world markets of certain products (Dukhnytskyi, 2019). The main risks of foreign economic activity of domestic subjects of agribusiness were investigated (Voronych, 2019).

Researchers are constantly in the field of view of topical problems of development of export potential of agro-industrial complex of Ukraine in the context of globalization and integration processes, the main positive and negative features of the historical trajectory of Ukraine's development in the context of globalization (Lazarieva, Vakar, 2019). The main trends in the expansion of exports of domestic agricultural products to the EU have been revealed and it is proved that the conditions of access of Ukrainian exporters to European agricultural markets are influenced by the systemic actions of EU regulatory policy (Golovachova, Iksarova, Kudyrko, 2018). The prospects of increasing the market presence of Ukrainian agricultural products in Asia were investigated, and the heterogeneity of the influence of various factors on the creation of international competitiveness for different types of agricultural products in different sales markets was proved; the threats of further expansion of the free trade zone (FTZ) between Ukraine and the EU were identified (Bosak, 2019). The institutional preconditions of functioning of agro-industrial complex of Ukraine were investigated, in particular, it was proved that the evolution of agrarian policy of EU is a forming factor of export potential of agro-industrial complex, the specifics of agricultural logistics and its influence on agro-industrial complex were defined (Okhrimenko, 2018).

Numerous works are aimed at assessing the export potential of individual subcomplexes of Ukrainian agro-industrial complex, especially grain products. The content of its export potential is determined and its components are singled out (Zrailo, 2019). The emphasis is made on the competitive advantages of the production of finished food products from grain and the ways of intensification of its processing using domestic demand and increasing exports of finished products are proposed (Lyakhovska, 2019). On the basis of assessment of the cost and expenditure components of the balance of grain crops the directions 
of improvement of their exports and imports are justified (Budziak, Budziak, 2020). The main trends and problems of Ukrainian exports of livestock products are investigated, and the directions of its growth on the EU market are proposed (Heraimovych, Humeniuk, Kubai, 2019). Priority directions of development of export potential of Ukrainian dairy industry in the conditions of activation of integration processes were determined (Popko, 2018). The prospects of commodity diversification of food exports to the EU and measures to strengthen the export potential of milk processing enterprises and dairy products production are substantiated (Melnyk, Samosudov, 2020). The activity of the main exporters of Ukrainian dairy products in 2014-2018 and the level of tariff and non-tariff protection of the EU market are assessed (Chesnik, Rozhko, Strus, 2019).

The system is proposed for the formation of the export potential of the agrarian sphere of the region (Nadvynychnyi, 2018). Noted the strategic importance of the agricultural sector in ensuring the foreign economic security of Ukraine (Urba, 2019).

Assessing the scientific papers on this issue, we believe that current trends in the development and implementation of the export potential of agricultural and food products of Ukraine are covered insufficiently and fragmentarily. There are no comprehensive studies combining its assessment by commodity and geographical structures (by regions and countries of the world), the system of export potential indicators in dynamics over a long period (the last 10 years), characterized by crisis changes due to escalation of military-political and economic confrontation with the Russian Federation and the introduction of quarantine measures related to COVID-19, find out the place of Ukrainian products on world food markets and compare with the largest partner countries in foreign agricultural trade, to study the factors and prospects of its formation and implementation, which determined the purpose of this research.

\section{Methodology}

To study the export potential of the agro-industrial complex of Ukraine, it was proposed to apply a comprehensive approach, which includes:

- analysis of the dynamics of commodity and geographical structure of foreign trade, in particular, export of agri-food products as a form of realization of export potential of Ukrainian agro-industrial complex in combination with identification of key factors influencing its formation;

- methods and inherent quantitative indicators to assess the success of the export potential of the country's agro-industrial complex, including comparison with the main partner countries of the world and the EU (to obtain a more realistic assessment of export potential), as well as with the regions of the world by commodity groups, in particular: the value of exports per capita of the country employed in the production of agricultural products; the ratio of exports of agricultural commodity groups to GDP (export quota); the ratio of exports of agricultural products to their production volume; the coefficient of net export potential; the coefficient of export efficiency of the country; the country's participation in the international division of labour; the indicator of comparative (relative) advantages of foreign trade (Formulas 1-5).

$$
E x q=\frac{E x_{i}}{G P}
$$

where is the ratio of exports of agricultural products to the volume of their production; $E x_{i}$ is the export of agricultural products to the $i$-th country; GP is the production of agricultural products in the country.

$$
C_{\text {exp }}=(E-I) / F T T \rightarrow \boldsymbol{m a x}
$$

where $C_{\exp }$ is the coefficient of net export potential; $E$ is the export of agricultural products of Ukraine; I - import of agricultural products of Ukraine; FTT Ukraine's foreign trade turnover in agricultural products.

$$
\mathrm{EEx}_{i} \mathrm{w}(\mathrm{EU})=\frac{\mathrm{Ex}_{i} / \mathrm{PP}_{\mathrm{i}} \cdot \mathrm{Ex}_{\mathrm{i}} / \mathrm{GP}_{\mathrm{w}(\mathrm{EU})} \cdot 100}{\mathrm{Ex}_{\mathrm{w}(\mathrm{EU})} / \mathrm{PP}_{\mathrm{w}(\mathrm{EU})} \cdot \mathrm{Ex}_{\mathrm{i}} / \mathrm{GP}_{\mathrm{i}}}
$$

where $\operatorname{EEx}_{i} \mathrm{w}(\mathrm{EU})$ is the export efficiency of the $i$-th country in the world (within the $\mathrm{EU}$ ); $\mathrm{Ex}_{\mathrm{i}} / \mathrm{PP}_{\mathrm{i}}$ is the export of the $i$-th c country per capita engaged in agricultural production; $\mathrm{Ex}_{\mathrm{i}} / \mathrm{GP}_{\mathrm{w}(\mathrm{EU})}$ is the share of exports of the $i$-th country in the production of agricultural products of the world (EU); $\mathrm{E}_{\mathrm{xw}(\mathrm{EU}) /}$ $\mathrm{PP}_{\mathrm{w}(\mathrm{EU})}$ - exports per capita in the world (EU), engaged in the production of agricultural products; $\mathrm{Ex}_{\mathrm{i}} / \mathrm{GP}_{\mathrm{i}}$ is the share of exports of the $i$-th country in its production of agricultural products.

$$
\mathrm{CPIDL}_{\mathrm{i}} \mathrm{w}(\mathrm{EU})=\frac{\mathrm{Ex}_{\mathrm{i}} / \mathrm{Ex}_{\mathrm{w}(\mathrm{EU})}}{\mathrm{GP}_{\mathrm{i}} / \mathrm{GP}_{\mathrm{w}(\mathrm{EU})}}
$$

where $\mathrm{CPIDL}_{\mathrm{iw}}(\mathrm{EU})$ is the coefficient of participation of the country in the international division of labor in the world (within the EU); $\mathrm{GP}_{\mathrm{i}}$ - production of agricultural products of the $i$-th country; $\mathrm{Ex}_{\mathrm{i}}$ is the export of the $i$-th country; $\mathrm{Ex}_{\mathrm{w}}$ - world exports (EU); $\mathrm{GP}_{\mathrm{w}}$ - production of agricultural products in the world (EU).

$$
R A_{i j}=\ln \left[\frac{E X_{i j} / I M_{i j}}{E X_{i} / I M_{i}}\right]
$$

where $R A_{i j}$ is an indicator of the relative (comparative) advantage of the $i$-th country for the $j$-th product; $E X_{i}, I M_{i}$ - export and import of the I-th country; $E X_{i j}, I M_{i j}$ - export and import of the $j$-th commodity of the $i$-th country. If $R A_{i j}>0$, the country has an 
advantage in foreign trade in certain goods. If $R A_{i j}<0$, then the country has no comparative advantage for that good/product group.

The arguments in favor of the proposed comprehensive approach are as follows: first, the resultsof a thorough analysis of the commodity and geographical structure of foreign trade in agricultural products of Ukraine in general and exports, in particular, as a form of realization of the export potential of agriculture are the basis for its assessment and are accompanied by the definition of the main factors of its formation; secondly, the use of quantitative indicators to assess the export potential makes it possible to determine the effectiveness of the export potential of the country's agro-industrial complex in comparison with other exporting countries and by commodity groups in trade with major regions of the world.

\section{Findings}

Ukraine has favourable natural and climatic conditions for the development of agriculture, temperature variations that do not pose a threat to crops, a favourable geographical location, the availability of water and land resources. Ukraine has 60.3 million hectares of land, which is $6 \%$ of Europe's territory. The area of agricultural land is 42.7 million hectares (70\% of Ukraine) and arable land is 32.5 million hectares (78.4\% of all agricultural land), including chernozems 17.4 million hectares ( $8 \%$ of the world's reserves) (StateGeoCadastre, 2020).

However, violation of the rules of crop rotation, the insufficient use of organic fertilizers and uncontrolled decline in groundwater level leads to erosion, pollution and degradation of soils (from 2000 to 2020, the fertility level of soils of Ukraine decreased by $3.14 \%$ ) (Lazarieva, 2019).

Ukraine's accession to the WTO, transition to international quality standards, liberalization of customs regimes within the framework of the Trade Facilitation Agreement (TFA), as noted in the paper of (Ladychenko, Tunitska, 2019), which contributed to the geographical diversification of foreign trade, were the stimulating factors for the export potential of the agricultural sector. Acquisition by Ukraine of the status of associated member of the EU and the signing of the Memorandum of Understanding "Dialogue on Agrarian Issues" between the Ministry of Agricultural Policy and Food of Ukraine and the DirectorateGeneral for Agriculture and Rural Development of the European Commission. With the entry into force of the Deep and Comprehensive Free Trade Area between Ukraine and the EU (DCFTA) on January 1, 2016, highly profitable EU markets were opened, which helped improve the quality of Ukrainian food and strengthen the food security of Ukraine, cooperation with international organizations and financial support for the development of Ukrainian agribusiness, including SMEs, is proved in the work (Melnyk, Tunitska, 2020).

The export potential of the country during the period under review has increased with the adoption and implementation of important regulations for the development of the agro-industrial complex of Ukraine, in particular, the State Target Programme for Rural Development in Ukraine for the period up to 2015, Agricultural Sector Development Strategy up to 2020, the Concept of the Ukrainian PublicPrivate Partnership Development Program for 2013-2018, justification of the Export Strategy for the Food and Processing Industry of Ukraine for 2019-2023.

However, the following factors have a negative impact on the export potential of Ukrainian agroindustrial complex: the volatility of the political situation, military intervention by the Russian Federation, the lack of satisfactory scientific validity of economic reforms; the low level of state support, the lack of effective mechanisms of investment risk insurance; significant state support by the U.S. and the EU of their national producers, which reduces the level of international competitiveness of Ukrainian food, forming a negative investment image of Ukraine; development of large agricultural holdings, which creates the risk of unemployment for farmworkers (today there are 14 million people living in rural areas, of which 3.6 million work in agriculture) (State Statistics Service of Ukraine, 2020); lack of legal regulation of genetic engineering in the country; technological backwardness of the vast majority of producers; high level of depreciation of fixed assets; use of extensive type of farming.

Throughout 2010-2020 foreign trade in agri-food products of Ukraine was characterized by the excess of annually growing volumes of exports over imports. Thus, in 2020 agricultural products worth 22,199.1 million USD were exported outside of Ukraine, which is $123 \%$ more than in 2010 (Table 1).

The dynamics of foreign trade growth was negatively affected by the military and political confrontation with the Russian Federation, as evidenced by the negative growth rates in 2013-2015. However, while during the next five years the growth rate of imports of agricultural products to Ukraine steadily increased by $10-13 \%$, the rate of exports was abrupt. In addition, due to quarantine restrictions related to the pandemic coronavirus COVID-19, the volume of exports in 2020 as a whole exceeded the figure for 2019 by only $0.2 \%$.

Since the beginning of the period under review, the share of agri-food exports in total Ukrainian exports has doubled to $45.1 \%$ in 2020 , even despite the COVID-19 global crisis. 
Table 1

Main indicators of foreign trade in agricultural products of Ukraine in 2010-2020

\begin{tabular}{|c|c|c|c|c|c|c|c|}
\hline Year & $\begin{array}{c}\text { Exports, } \\
\text { million USD }\end{array}$ & $\begin{array}{c}\text { Imports, } \\
\text { million USD }\end{array}$ & $\begin{array}{c}\text { Export surplus, } \\
\text { million USD }\end{array}$ & $\begin{array}{c}\text { External } \\
\text { turnover, } \\
\text { million USD }\end{array}$ & $\begin{array}{c}\text { Exports } \\
\text { increase rate, \% }\end{array}$ & $\begin{array}{c}\text { Import increase } \\
\text { rate, \% }\end{array}$ & $\begin{array}{c}\text { Foreign trade } \\
\text { increase rate, \% }\end{array}$ \\
\hline 2010 & 9936,1 & 5761,9 & 4174,2 & 15698 & - & - & - \\
\hline 2011 & 12804,1 & 6346,7 & 6457,4 & 19150,8 & 28,9 & 10,1 & 22 \\
\hline 2012 & 17880,6 & 7519,7 & 10360,9 & 25400,3 & 39,6 & 18,5 & 32,6 \\
\hline 2013 & 17024,3 & 8184 & 8840,3 & 25208,3 & $-4,8$ & 8,8 & $-0,8$ \\
\hline 2014 & 16669 & 6059,3 & 10609,7 & 22728,3 & $-2,1$ & -26 & $-9,8$ \\
\hline 2015 & 14563,1 & 3484,4 & 11078,7 & 18047,5 & $-12,6$ & $-42,5$ & $-20,6$ \\
\hline 2016 & 15281,8 & 3891,1 & 11390,7 & 19172,9 & 4,9 & 11,7 & 6,2 \\
\hline 2017 & 17756,9 & 4301,2 & 13455,7 & 22058,1 & 16,2 & 10,5 & 15 \\
\hline 2018 & 18611,8 & 5055,5 & 13556,3 & 23667,3 & 4,8 & 17,5 & 7,3 \\
\hline 2019 & 22144,2 & 5736 & 16408,2 & 27880,2 & 19 & 13,5 & 17,8 \\
\hline 2020 & 22199,1 & 6495,5 & 15703,7 & 28694,6 & 0,2 & 13,2 & 2,9 \\
\hline
\end{tabular}

Source: calculated by the author according to the State Statistics Service of Ukraine

Table 2

Dynamics of the geographical structure of agricultural foreign trade of Ukraine in 2010-2020, \%

\begin{tabular}{|c|c|c|c|c|c|c|c|c|c|}
\hline Region & Indicator & 2010 & 2014 & 2015 & 2016 & 2017 & 2018 & 2019 & 2020 \\
\hline \multirow{2}{*}{ CIS } & Export & 33,5 & 14,8 & 10,0 & 7,5 & 7,6 & 8,0 & 6,5 & 5,9 \\
\hline & Import & 14,0 & 12,0 & 9,0 & 3,8 & 3,2 & 3,4 & 4,0 & 3,9 \\
\hline \multirow{2}{*}{ Europe } & Export & 20,4 & 28,6 & 27,9 & 27,1 & 32,1 & 33,1 & 33,2 & 29,6 \\
\hline & Import & 43,0 & 46,6 & 48,5 & 50,1 & 53,8 & 54,9 & 56,3 & 57,0 \\
\hline \multirow{2}{*}{ Asia } & Export & 31,4 & 40,7 & 47,1 & 48,2 & 44,7 & 44,8 & 43,7 & 50,2 \\
\hline & Import & 19,4 & 21,2 & 22,3 & 24,5 & 22,6 & 22,1 & 20,6 & 20,7 \\
\hline \multirow{2}{*}{ Africa } & Export & 13,8 & 15,3 & 13,8 & 15,9 & 14,3 & 12,5 & 15,0 & 13,0 \\
\hline & Import & 5,8 & 4,7 & 5,7 & 5,1 & 5,1 & 5,1 & 4,4 & 4,6 \\
\hline \multirow{2}{*}{ America } & Export & 0,4 & 0,4 & 0,8 & 0,8 & 0,7 & 1,0 & 1,0 & 0,8 \\
\hline & Import & 17,5 & 14,2 & 13,7 & 15,6 & 14,2 & 13,4 & 13,6 & 13,4 \\
\hline \multirow{2}{*}{$\begin{array}{c}\text { Australia and } \\
\text { Oceania }\end{array}$} & Export & 0,0 & 0,0 & 0,0 & 0,0 & 0,0 & 0,1 & 0,1 & 0,1 \\
\hline & Import & 0,2 & 0,8 & 0,3 & 0,3 & 0,3 & 0,3 & 0,3 & 0,4 \\
\hline \multirow{2}{*}{\begin{tabular}{|c|}
$\begin{array}{c}\text { Other unspecified } \\
\text { countries }\end{array}$ \\
\end{tabular}} & Export & 0,5 & 0,1 & 0,4 & 0,5 & 0,5 & 0,5 & 0,4 & 0,3 \\
\hline & Import & 0,0 & 0,5 & 0,5 & 0,5 & 0,8 & 0,8 & 0,8 & - \\
\hline
\end{tabular}

Source: calculated by the author according to the State Statistics Service of Ukraine

Table 3

Geographical structure of Ukrainian agro-industrial products exports in 2020, \% (TOP-10)

\begin{tabular}{|l|c|l|l|l|l|l|l|l|l|l|l|l|}
\hline \multicolumn{2}{|c|}{ Europe } & \multicolumn{3}{c|}{ Asia } & \multicolumn{2}{c|}{ Africa } & \multicolumn{2}{c|}{ America } & \multicolumn{2}{c|}{ Australia and Oceania } \\
\hline Netherlands & 21,6 & Belarus & 38,9 & China & 32,0 & Egypt & 47,4 & USA & 57,5 & Australia & 72,9 \\
\hline Spain & 15,0 & $\begin{array}{l}\text { Republic of } \\
\text { Moldova }\end{array}$ & 17,8 & India & 13,5 & Tunisia & 12,4 & Mexico & 7,9 & New Zealand & 13,6 \\
\hline Poland & 11,6 & Azerbaijan & 13,0 & Turkey & 9,6 & Morocco & 11,7 & Canada & 6,8 & Tuvalu & 3,3 \\
\hline Germany & 8,8 & Kazakhstan & 11,1 & Indonesia & 5,1 & Libya & 10,3 & Brazil & 5,8 & New Caledonia & 1,9 \\
\hline Italy & 8,6 & Armenia & 5,6 & Saudi Arabia & 3,9 & Algeria & 5,9 & Costa Rica & 4,8 & Fiji & 0,6 \\
\hline UK & 5,8 & Russian Federation & 5,3 & Iraq & 3,6 & Ethiopia & 1,5 & Ecuador & 3,3 & Marshall Islands & 0,5 \\
\hline Belgium & 5,7 & $\begin{array}{l}\text { Republic of } \\
\text { Uzbekistan }\end{array}$ & 4,2 & Israel & 3,4 & Mauritania & 1,2 & Suriname & 2,8 & $\begin{array}{l}\text { Papua New } \\
\text { Guinea }\end{array}$ & 0,4 \\
\hline France & 5,5 & Kyrgyz Republic & 1,8 & Bangladesh & 3,1 & $\begin{array}{l}\text { Republic of } \\
\text { Kenya }\end{array}$ & 1,2 & Venezuela & 2,1 & French Polynesia & 0,1 \\
\hline Portugal & 2,4 & Turkmenistan & 1,3 & Republic of Korea & 2,7 & Mozambique & 0,9 & Peru & 1,9 & Palau & 0,0 \\
\hline Romania & 2,3 & $\begin{array}{l}\text { Republic of } \\
\text { Tajikistan }\end{array}$ & 0,8 & Lebanon & 2,6 & South Africa & 0,8 & Guyana & 1,5 & Cook Islands & 0,0 \\
\hline Others & 12,7 & Others & 0,2 & Others & 20,5 & Others & 6,7 & Others & 5,6 & Others & 6,7 \\
\hline
\end{tabular}

Source: calculated by the author according to the State Statistics Service of Ukraine 
The key markets for domestic agricultural products remain three regions: Asia (China, India, Turkey, Indonesia, etc.), Africa (Egypt, Tunisia, Morocco, Libya, etc.), Europe (including the Netherlands, Spain, Poland, Germany, etc.) (Tables 2, 3). In 2020, their total share was more than $98 \%$ of the value of Ukrainian agricultural exports. The status of the main importers of Ukrainian agricultural products has passed to Asian countries, whose share in 2010-2020 increased from 31 to $50.2 \%$, while the same indicator of former strategic partners - the CIS countries decreased in 5 times and amounted to $6 \%$ in 2020.

Only countries in the Asian region increased the volume of Ukrainian food imports during quarantine measures due to COVID-19. Although European countries accounted for one-third of Ukraine's agricultural exports over the past three years, their share in the region dropped from $33.2 \%$ in 2019 to $29.6 \%$ in 2020 . Analysis of the global market for agricultural and grocery products revealed an almost threefold increase in demand for agroindustrial products over the past 10 years due to the aggravation of the global problem of hunger. In 2019, 820 million people suffered from it, including $8 \%$ of the population of developed countries in North America and Europe (FAO, 2020).

In 2020 , finished food products (37.7\%) held the largest share in the structure of world exports, ahead of plant products $(33.1 \%)$, live animals; animal products (22.9\%); fats and oils held the smallest share (6.3\%). The list of commodity groups has been identified for which demand will grow over 2010-2020, as evidenced by their dynamics and share in world exports (see Table 4). These are meat and edible offal; fish and crustaceans; milk and dairy products, poultry eggs; natural honey; vegetables; edible fruits and nuts; grains; seeds and fruits of oilseeds; fats and oils of animal or vegetable origin; prepared grain products; processed vegetable products; various food products; alcoholic and soft drinks and vinegar; food industry residues and wastes. In 2020, their share of total world exports is $4-9 \%$, and their combined share is $80 \%$.

The development of Ukraine's exports does not correspond to global trends. The basis of Ukrainian exports over the past 10 years are only 4 commodity groups: cereals (6th place among world exporters in 2020); seeds and oilseeds (8th place); fats and oils of animal or vegetable origin (5th place) and residues and wastes of food industry (16th place), the total share of which in the structure of Ukrainian agricultural exports in 2020 was $84 \%$.

This trend is quite positive in terms of maintaining a highly competitive niche in export supplies and their expansion. However, it is necessary to accelerate the search for ways to diversify commodity exports through the supply of products that require deep technological processing of vegetable and livestock raw materials. Contrary to the global trend in the structure of demand, the share of finished food products decreased from 26 to $15 \%$ in the total structure of exports of Ukrainian agro-industrial complex due to the reduction by half on average of the already small export share of all product groups, except for food industry waste. The share of milk and dairy products, poultry eggs; natural honey; vegetables, edible nuts and fruits; meat and fish products; cocoa and cocoa products; finished grain products; processed vegetable products; alcoholic and soft drinks and vinegar decreased by 1.5-3 times. The decline in the share of the above mentioned Ukrainian goods in their world exports indicates that Ukraine is gradually losing its competitive position on the international market of these goods (Table 4).

Economically developed countries of the world, having an established system of crop rotation management and realizing the significant effect of soil depletion from growing such traditional exportoriented crops as sunflower, corn and rapeseed for Ukraine, import them and products of primary processing. Instead, Ukraine exports raw materials that, after processing in developed countries, return in the form of finished food products with high added value. Thus, compared with 2010, their share in total imports of agricultural products has increased from 44 to $52 \%$, in particular, the share of imports of meat and fish products, finished grain products, alcohol, various foods, tobacco products and dairy products has increased by half or two times.

The orientation of Ukrainian exporters to a limited number of agri-food commodity groups is also erroneous, given the dependence of the efficiency of export operations on seasonal fluctuations in world prices for these products, mainly grain, whose main competitive advantage is a relatively low cost.

Table 5 shows that despite the increase in exports, there is a growing negative balance due to excess imports in such commodity groups of agriculture as fish and crustaceans; other products of animal origin; vegetables; edible fruits and nuts; coffee, tea. Rapid deterioration of the foreign trade balance against the background of decreased export and increased import occurred in milk and dairy products, poultry eggs, natural honey, meat products, fish, alcoholic and nonalcoholic beverages, and vinegar. Negative balance and a decrease in exports are characteristic of cocoa and cocoa products; finished grain products and processed vegetable products.

In the long term, to ensure a highly competitive position on the international food market, Ukraine should not rely solely on the development of agricultural exports, given the average global level of its export potential. In 2019, for example, the vast 
Table 4

Comparison of the dynamics and structure of agricultural exports of the world and Ukraine in 2010-2020

\begin{tabular}{|c|c|c|c|c|c|c|c|c|c|c|}
\hline \multirow[t]{2}{*}{$\begin{array}{l}\text { Section, UKTZED group and } \\
\text { product name }\end{array}$} & \multicolumn{2}{|c|}{$\begin{array}{c}\text { Increase in exports } \\
\text { of agricultural } \\
\text { products in } 2020 \\
\text { to } 2010, \%\end{array}$} & \multicolumn{2}{|c|}{$\begin{array}{l}\text { Share of world } \\
\text { exports of goods in } \\
\text { total world exports } \\
\text { of agricultural } \\
\text { products, } \%\end{array}$} & \multicolumn{2}{|c|}{$\begin{array}{c}\text { Share of } \\
\text { commodity } \\
\text { exports in the } \\
\text { total exports } \\
\text { of agricultural } \\
\text { products of } \\
\text { Ukraine, \% }\end{array}$} & \multicolumn{2}{|c|}{$\begin{array}{c}\text { Share of Ukrainian } \\
\text { exports in total } \\
\text { world exports } \\
\text { of agricultural } \\
\text { products, \% }\end{array}$} & \multicolumn{2}{|c|}{$\begin{array}{l}\text { The place of } \\
\text { Ukraine in the } \\
\text { world rankings }\end{array}$} \\
\hline & World & Ukraine & 2010 & 2020 & 2010 & 2020 & 2010 & 2020 & 2010 & 2020 \\
\hline TOTAL AIC & 33,8 & 123,4 & 100 & 100 & 19,3 & 45,1 & 0,9 & 1,4 & - & - \\
\hline $\begin{array}{l}\text { I. Live animals; products of animal } \\
\text { origin }\end{array}$ & 29,5 & 54,1 & 23,4 & 22,9 & 7,8 & 5,4 & 0,3 & 0,3 & - & - \\
\hline 01 live animals & 23,5 & 1316,8 & 1,7 & 1,4 & 0 & 0,2 & 0,1 & 0,2 & 84 & 46 \\
\hline 02 meat and edible offal & 36,8 & 623,3 & 8,6 & 8,6 & 0,9 & 2,9 & 0,1 & 0,5 & 44 & 27 \\
\hline 03 fish and crustaceans & 24,5 & 100,9 & 6,8 & 6,5 & 0,2 & 0,2 & 0,01 & 0,0 & 88 & 84 \\
\hline $\begin{array}{l}04 \text { milk and dairy products, } \\
\text { poultry eggs; natural honey }\end{array}$ & 25,7 & $-34,2$ & 5,7 & 5,7 & 6,5 & 1,9 & 0,9 & 0,5 & 20 & 31 \\
\hline 05 other products of animal origin & 39,5 & 103,2 & 0,6 & 0,6 & 0,1 & 0,1 & 0,1 & 0,2 & 50 & 52 \\
\hline II. Vegetable products & 42,3 & 199,0 & 30,9 & 33,1 & 40 & 53,6 & 1,11 & 2,3 & - & - \\
\hline 06 live trees and other plants & 23,4 & 222,4 & 1,7 & 1,4 & 0 & 0 & 0,0 & 0,0 & 81 & 70 \\
\hline 07 vegetables & 26,9 & 41,0 & 4,6 & 4,6 & 1,2 & 0,8 & 0,2 & 0,2 & 46 & 37 \\
\hline 08 edible fruits and nuts & 56,1 & 14,2 & 6,5 & 7,7 & 2,1 & 1,1 & 0,3 & 0,2 & 47 & 50 \\
\hline 09 coffee, tea & 32,2 & 52,1 & 2,9 & 3,1 & 0,1 & 0,1 & 0,0 & 0,0 & 92 & 83 \\
\hline 10 cereals (grain crops) & 39,3 & 281,7 & 7,6 & 7,6 & 24,8 & 42,4 & 2,9 & 8,0 & 11 & 6 \\
\hline $\begin{array}{l}11 \text { products of flour and cereals } \\
\text { industry }\end{array}$ & 32,8 & 91,0 & 1,4 & 1,2 & 0,8 & 0,7 & 0,3 & 0,8 & 58 & 25 \\
\hline 12 seeds and oleaginous fruits & 56,4 & 69,7 & 5,7 & 6,9 & 10,9 & 8,3 & 1,6 & 1,7 & 10 & 8 \\
\hline 13 natural shellac & 34,7 & $-25,1$ & 0,5 & 0,5 & 0 & 0 & 0,0 & 0,0 & 65 & 78 \\
\hline $\begin{array}{l}14 \text { vegetable materials for the } \\
\text { manufacture }\end{array}$ & 35,3 & 2710,9 & 0,1 & 0,1 & 0 & 0,2 & 0,2 & 4,0 & 52 & 9 \\
\hline $\begin{array}{l}\text { III } 15 \text { fats and oils of animal or } \\
\text { vegetable origin }\end{array}$ & 21,3 & 120,1 & 6,4 & 6,3 & 26,3 & 25,9 & 3,3 & 5,9 & 7 & 3 \\
\hline IV. Finished food products & 31,9 & 30,7 & 39,3 & 37,7 & 25,9 & 15,1 & 0,6 & 0,6 & - & - \\
\hline 16 meat and fish products & 36,9 & $-53,6$ & 3,4 & 3,3 & 0,5 & 0,1 & 0,1 & 0,0 & 60 & 78 \\
\hline 17 sugar and sugar confectionery & $-6,7$ & 21,2 & 3,4 & 2,7 & 2,1 & 1,1 & 0,5 & 0,6 & 38 & 24 \\
\hline 18 cocoa and cocoa products & 3,6 & $-66,0$ & 3,3 & 2,6 & 6 & 0,9 & 1,6 & 0,5 & 19 & 32 \\
\hline 19 finished grain products & 61,8 & 23,1 & 4,4 & 5,0 & 2,6 & 1,4 & 0,5 & 0,4 & 33 & 40 \\
\hline 20 vegetable processing products & 29,0 & $-17,9$ & 4,4 & 4,0 & 2,1 & 0,8 & 0,4 & 0,3 & 33 & 44 \\
\hline 21 different food products & 72,2 & 29,9 & 4,3 & 5,3 & 1,2 & 0,7 & 0,3 & 0,2 & 51 & 56 \\
\hline $\begin{array}{l}22 \text { alcoholic and non-alcoholic } \\
\text { beverages and vinegar }\end{array}$ & 32,5 & $-49,6$ & 7,8 & 7,5 & 4,5 & 1 & 0,5 & 0,2 & 31 & 47 \\
\hline 23 food industry residues and wastes & 41,1 & 229,1 & 5,0 & 5,1 & 4,8 & 7,1 & 0,3 & 2,0 & 31 & 16 \\
\hline $\begin{array}{l}24 \text { tobacco and industrial tobacco } \\
\text { substitutes }\end{array}$ & $-1,3$ & 106,3 & 3,4 & 2,3 & 2,2 & 2 & 0,6 & 1,3 & 37 & 26 \\
\hline
\end{tabular}

Source: calculated by the author according to the State Statistics Service of Ukraine, the World Bank, FAO, TrendEconomy, and UN Comtrade

majority of Ukraine's largest trading partners were at a much higher level in terms of agricultural production per capita engaged in the farming sector; in terms of exports of agricultural products per capita, which amounted to 5864.8 U.S. dollars per capita, Ukraine was ahead of some CIS and Asian countries, giving way to economically developed countries and world leaders in the production and export of food the Netherlands (445684.9 USD per capita), Canada (142361.3 USD per capita), Germany (110221.0 USD per capita), etc. (Table 6). Although Ukraine partici- pates quite actively in the international division of labour in agriculture, as evidenced by the size of the export quota (35.9\%) and its level is higher than that of the selected partner countries, the net export ratio is the highest in the sample - 0.5 (except for Brazil and New Zealand), and the international division of labour in agriculture is above 1 (2.0), such active participation is not accompanied by a corresponding level of export efficiency.

In general, agricultural export efficiency, which shows the per capita income of each percent of 
Vol. 7 No. 5, 2021

Baltic Journal of Economic Studies

Table 5

Ukraine's foreign trade in agro-industrial products in 2010-2020

\begin{tabular}{|c|c|c|c|c|c|c|c|c|c|c|}
\hline \multirow{2}{*}{$\begin{array}{l}\text { Section, } \\
\text { product } \\
\text { group } \\
\text { UKTZED }\end{array}$} & \multicolumn{2}{|c|}{ Exports, million USD } & \multicolumn{2}{|c|}{$\begin{array}{c}\text { Share of goods in total } \\
\text { exports, \% }\end{array}$} & \multicolumn{2}{|c|}{ Imports, million USD } & \multicolumn{2}{|c|}{$\begin{array}{c}\text { Share of goods in total } \\
\text { imports, } \%\end{array}$} & \multicolumn{2}{|c|}{$\begin{array}{l}\text { Foreign trade balance, } \\
\text { million USD }\end{array}$} \\
\hline & 2010 & 2020 & 2010 & 2020 & 2010 & 2020 & 2010 & 2020 & 2010 & 2020 \\
\hline I. & 771,4 & 1188,4 & 7,8 & 5,4 & 1241,7 & 1257,8 & 21,6 & 21,9 & $-470,3$ & $-69,4$ \\
\hline 01 & 3,6 & 51,5 & 0 & 0,2 & 67,5 & 80,9 & 1,2 & 1,4 & $-63,9$ & $-29,4$ \\
\hline 02 & 90,2 & 652,2 & 0,9 & 2,9 & 458,0 & 165,0 & 7,9 & 2,9 & $-367,8$ & 487,2 \\
\hline 03 & 21,0 & 42,2 & 0,2 & 0,2 & 568,6 & 680,3 & 9,9 & 11,9 & $-547,6$ & $-638,1$ \\
\hline 04 & 648,8 & 426,6 & 6,5 & 1,9 & 135,4 & 308,4 & 2,4 & 5,4 & 513,3 & 118,2 \\
\hline 05 & 7,8 & 15,8 & 0,1 & 0,1 & 12,2 & 23,2 & 0,2 & 0,4 & $-4,4$ & $-7,4$ \\
\hline II. & 3976,3 & 11890,1 & 40 & 53,7 & 1563,7 & 1988,3 & 27,1 & 34,7 & 2412,6 & 9901,7 \\
\hline 06 & 1,8 & 5,7 & 0 & 0 & 73,9 & 48,8 & 1,3 & 0,9 & $-72,1$ & $-43,0$ \\
\hline 07 & 119,2 & 168,1 & 1,2 & 0,8 & 129,9 & 262,5 & 2,3 & 4,6 & $-10,7$ & $-94,4$ \\
\hline 08 & 208,8 & 238,4 & 2,1 & 1,1 & 733,3 & 794,9 & 12,7 & 13,9 & $-524,5$ & $-556,5$ \\
\hline 09 & 9,9 & 15,0 & 0,1 & 0,1 & 234,1 & 251,3 & 4,1 & 4,4 & $-224,2$ & $-236,3$ \\
\hline 10 & 2467,1 & 9417,3 & 24,8 & 42,5 & 145,6 & 178,9 & 2,5 & 3,1 & 2321,5 & 9238,4 \\
\hline 11 & 80,9 & 154,6 & 0,8 & 0,7 & 27,5 & 35,2 & 0,5 & 0,6 & 53,5 & 119,5 \\
\hline 12 & 1085,7 & 1842,4 & 10,9 & 8,3 & 178,9 & 388,0 & 3,1 & 6,8 & 906,7 & 1454,4 \\
\hline 13 & 1,3 & 0,9 & 0 & 0 & 39,6 & 28,0 & 0,7 & 0,5 & $-38,4$ & $-27,1$ \\
\hline 14 & 1,7 & 47,4 & 0 & 0,2 & 0,9 & 0,7 & 0,0 & 0,0 & 0,8 & 46,7 \\
\hline III 15 & 2617,3 & 5759,6 & 26,3 & 26 & 451,5 & 280,4 & 7,8 & 4,9 & 2165,8 & 5479,2 \\
\hline IV. & 2571,1 & 3361,1 & 25,9 & 15,2 & 2504,9 & 2969,0 & 43,5 & 51,8 & 66,1 & 392,2 \\
\hline 16 & 48,7 & 22,6 & 0,5 & 0,1 & 100,3 & 160,6 & 1,7 & 2,8 & $-51,6$ & $-138,0$ \\
\hline 17 & 206,5 & 250,2 & 2,1 & 1,1 & 231,4 & 74,1 & 4,0 & 1,3 & $-24,9$ & 176,1 \\
\hline 18 & 591,6 & 201,4 & 6 & 0,9 & 407,3 & 375,9 & 7,1 & 6,6 & 184,3 & $-174,5$ \\
\hline 19 & 254,3 & 313,1 & 2,6 & 1,4 & 125,8 & 241,5 & 2,2 & 4,2 & 128,5 & 71,6 \\
\hline 20 & 210,4 & 172,6 & 2,1 & 0,8 & 223,3 & 209,0 & 3,9 & 3,6 & $-12,9$ & $-36,4$ \\
\hline 21 & 122,9 & 159,6 & 1,2 & 0,7 & 466,5 & 484,9 & 8,1 & 8,5 & $-343,5$ & $-325,3$ \\
\hline 22 & 443,7 & 223,7 & 4,5 & 1 & 270,6 & 587,4 & 4,7 & 10,2 & 173,1 & $-363,8$ \\
\hline 23 & 479,1 & 1576,5 & 4,8 & 7,1 & 208,4 & 278,0 & 3,6 & 4,8 & 270,6 & 1298,5 \\
\hline 24 & 213,9 & 441,4 & 2,2 & 2 & 471,4 & 557,5 & 8,2 & 9,7 & $-257,5$ & $-116,1$ \\
\hline
\end{tabular}

Source: calculated by the author according to the State Statistics Service of Ukraine

GDP (agricultural) exported compared to the world average, taken as $100 \%$. The more a country exports per capita and the lower the share of exports in GDP (agriculture), the higher the economic efficiency of exports. According to our calculations, Ukraine is characterized by an export efficiency slightly above the world average of 3.2 or $320 \%$, ahead of the CIS countries (not including the Russian Federation).

While the level of export efficiency of developed partner countries (Netherlands, Germany, France, USA, Canada) is 20-200 times higher than the world average. Such a striking lag of Ukraine according to this indicator is connected, first of all, with the distorted commodity structure of agricultural export, drawbacks of state regulation, degradation of science and lack of advanced technologies in the industry.

A comparative analysis of the export potential of Ukraine and the EU also showed a low level of export efficiency of Ukraine, despite the significant level of participation in the international division of labour, the share of exports in agricultural products and export quotas. The increase in production is achieved primarily due to the number of employees, much higher than in the EU, which indicates the technological lag of Ukrainian producers from economically developed countries (Table 7).

Ukraine is one of the leaders in the world export market of food products with a limited number of agricultural products - raw materials and semifinished products. However, it is obvious that there are significant reserves to increase food supplies to traditional and other countries through the introduction of deeper technological processing.

The results of calculation of the indices of relative advantages, which characterize the realized export potential of the agro-industrial complex as a whole in trade of Ukraine with other regions of the world in 2010-2020 and determination of the priority of export of commodity groups are presented in Tables 8 and 9. For those commodity items, which in the initial data showed no exports or imports, the index of comparative advantage could not be calculated, which indicates the implementation of only 
Table 6

Comparison of the export potential of the farming sector of Ukraine and major trading partners, 2019*

\begin{tabular}{|c|c|c|c|c|c|c|c|}
\hline State & $\begin{array}{l}\text { Production of } \\
\text { agricultural } \\
\text { products } \\
\text { per person } \\
\text { employed in } \\
\text { agriculture, } \\
\text { USD }\end{array}$ & $\begin{array}{l}\text { Exports of } \\
\text { agricultural } \\
\text { products } \\
\text { per person } \\
\text { employed in } \\
\text { the agricultural } \\
\text { sector, USD }\end{array}$ & $\begin{array}{c}\text { Export quota, } \\
\%\end{array}$ & $\begin{array}{l}\text { Ratio of } \\
\text { agricultural } \\
\text { exports to } \\
\text { production } \\
\text { volume, \% }\end{array}$ & $\begin{array}{l}\text { Net exports } \\
\text { ratio }\end{array}$ & $\begin{array}{l}\text { Coefficient of } \\
\text { participation } \\
\text { in the int. } \\
\text { division of } \\
\text { labour }\end{array}$ & $\begin{array}{c}\text { Export } \\
\text { efficiency } \\
\text { coefficient }\end{array}$ \\
\hline Ukraine & 16341,7 & 5864,8 & 11,48 & 35,9 & 0,5 & 2,0 & 3,2 \\
\hline Netherlands & 106937,4 & 445684,9 & 8,25 & 416,8 & 0,2 & 23,5 & 88,0 \\
\hline Spain & 65527,1 & 56083,8 & 3,21 & 85,6 & 0,2 & 4,8 & 32,2 \\
\hline Poland & 20889,4 & 14817,3 & 3,73 & 70,9 & 0,1 & 4,0 & 5,1 \\
\hline Germany & 97821,4 & 110221,0 & 1,46 & 112,7 & $-0,2$ & 6,4 & 60,5 \\
\hline Italy & 42195,2 & 39122,7 & 1,77 & 92,7 & $-0,1$ & 5,2 & 16,5 \\
\hline United Kingdom & 84590,3 & 45107,0 & 0,54 & 53,3 & $-0,5$ & 3,0 & 14,3 \\
\hline France & 86843,3 & 75740,8 & 1,89 & 87,2 & 0,1 & 4,9 & 49,1 \\
\hline Belarus & 20919,9 & 6944,7 & 5,98 & 33,2 & 0,0 & 1,9 & 0,9 \\
\hline Republic of Moldova & 16329,6 & 6909,0 & 10,55 & 42,3 & 0,4 & 2,4 & 0,2 \\
\hline Azerbaijan & 3070,4 & 444,4 & 1,64 & 14,5 & $-0,4$ & 0,8 & 0,0 \\
\hline Armenia & 6553,7 & 1510,4 & 2,58 & 23,0 & $-0,3$ & 1,3 & 0,0 \\
\hline Russian Federation & 23357,9 & 4187,2 & 1,03 & 17,9 & $-0,1$ & 1,0 & 4,5 \\
\hline Kazakhstan & 13612,9 & 2685,9 & 1,77 & 19,7 & 0,0 & 1,1 & 0,5 \\
\hline India & 2828,9 & 146,3 & 0,00 & 5,2 & 0,0 & 0,3 & 0,7 \\
\hline Turkey & 13585,9 & 4013,9 & 0,77 & 29,5 & 0,0 & 1,7 & 3,0 \\
\hline Israel & 110641,1 & 37967,7 & 2,68 & 34,3 & $-0,5$ & 1,9 & 1,7 \\
\hline Republic of Korea & 11050,9 & 2573,9 & 0,36 & 23,3 & $-0,7$ & 1,3 & 0,4 \\
\hline Egypt & 6414,3 & 1080,0 & 0,35 & 16,8 & $-0,4$ & 1,0 & 0,4 \\
\hline USA & 170469,4 & 54880,4 & 0,22 & 32,2 & 0,1 & 1,8 & 219,8 \\
\hline Canada & 176343,6 & 142361,3 & 1,96 & 80,7 & 0,1 & 4,6 & 79,5 \\
\hline Brazil & 29351,0 & 11187,1 & 0,55 & 38,1 & 0,8 & 2,2 & 30,3 \\
\hline Australia & 112985,2 & 64085,4 & 2,36 & 56,7 & 0,3 & 3,2 & 26,3 \\
\hline New Zealand & 110636,4 & 124850,1 & 5,11 & 112,8 & 0,7 & 6,4 & 23,9 \\
\hline
\end{tabular}

* Data on global agricultural exports in 2020 is not fully available

Source: calculated by the author according to the State Statistics Service of Ukraine, FAO, and ILO

Table 7

Comparison of indicators of export potential of agro-industrial complex of Ukraine and EU countries, 2020

\begin{tabular}{|l|c|c|c|c|c|c|c|}
\hline State & $\begin{array}{c}\text { Agricultural } \\
\text { production per } \\
\text { capita employed in } \\
\text { agribusiness, USD }\end{array}$ & $\begin{array}{c}\text { Exports of } \\
\text { AIC per capita } \\
\text { employed in } \\
\text { AIC, USD }\end{array}$ & $\begin{array}{c}\text { Export quota, } \\
\%\end{array}$ & $\begin{array}{c}\text { Ratio of } \\
\text { agricultural exports } \\
\text { to production } \\
\text { volume, } \%\end{array}$ & $\begin{array}{c}\text { Net exports } \\
\text { ratio }\end{array}$ & $\begin{array}{c}\text { Coefficient of } \\
\text { participation in } \\
\text { the int. division } \\
\text { of labour }\end{array}$ & $\begin{array}{c}\text { Export } \\
\text { efficiency } \\
\text { coefficient }\end{array}$ \\
\hline Ukraine & 14361,3 & 6559,0 & 14,23 & 45,7 & 0,6 & 1,2 & 0,5 \\
\hline Austria & 147640,3 & 61753,0 & 3,66 & 41,8 & 0,0 & 1,1 & 3,5 \\
\hline Belgium & 411886,0 & 259771,5 & 7,61 & 63,1 & 0,1 & 1,7 & 24,6 \\
\hline Bulgaria & 36696,1 & 17887,0 & 8,47 & 48,7 & 0,1 & 1,3 & 0,3 \\
\hline Greece & 60018,1 & 15191,6 & 4,43 & 25,3 & 0,0 & 0,7 & 0,8 \\
\hline Denmark & 338491,5 & 213003,5 & 6,56 & 62,9 & 0,2 & 1,6 & 11,9 \\
\hline Estonia & 121460,1 & 56114,1 & 6,51 & 46,2 & $-0,1$ & 1,2 & 0,4 \\
\hline Ireland & 268344,5 & 111704,0 & 3,86 & 41,6 & 0,2 & 1,1 & 6,6 \\
\hline Cyprus & 100807,2 & 21114,0 & 2,17 & 20,9 & $-0,4$ & 0,5 & 0,1 \\
\hline Latvia & 64448,2 & 37743,1 & 10,61 & 58,6 & 0,0 & 1,5 & 0,3 \\
\hline Lithuania & 81427,8 & 60808,6 & 13,26 & 74,7 & 0,2 & 2,0 & 0,9 \\
\hline Luxembourg & 236985,0 & 674413,8 & 2,00 & 284,6 & $-0,4$ & 7,5 & 0,5 \\
\hline Malta & 122244,0 & 44888,2 & 2,06 & 36,7 & $-0,4$ & 1,0 & 0,1 \\
\hline Portugal & 108921,4 & 31874,7 & 4,01 & 29,3 & $-0,2$ & 0,8 & 1,5 \\
\hline Romania & 23576,2 & 4547,9 & 3,48 & 19,3 & $-0,1$ & 0,5 & 0,3 \\
\hline
\end{tabular}




\begin{tabular}{|l|c|c|c|c|c|c|c|}
\hline \multicolumn{1}{|c|}{ State } & $\begin{array}{c}\text { Agricultural } \\
\text { production per } \\
\text { capita employed in } \\
\text { agribusiness, USD }\end{array}$ & $\begin{array}{c}\text { Exports of } \\
\text { AIC per capita } \\
\text { employed in } \\
\text { AIC, USD }\end{array}$ & $\begin{array}{c}\text { Export quota, } \\
\%\end{array}$ & $\begin{array}{c}\text { Ratio of } \\
\text { agricultural exports } \\
\text { to production } \\
\text { volume, } \%\end{array}$ & $\begin{array}{c}\text { Net exports } \\
\text { ratio }\end{array}$ & $\begin{array}{c}\text { Coefficient of } \\
\text { participation in } \\
\text { the int. division } \\
\text { of labour }\end{array}$ & $\begin{array}{c}\text { Export } \\
\text { efficiency } \\
\text { coefficient }\end{array}$ \\
\hline Slovakia & 79588,7 & 32387,0 & 3,73 & 40,7 & $-0,2$ & 1,1 & 0,5 \\
\hline Slovenia & 80046,3 & 33778,9 & 3,61 & 42,2 & $-0,2$ & 1,1 & 0,2 \\
\hline Hungary & 69230,8 & 33196,0 & 7,64 & 47,9 & 0,2 & 1,3 & 1,2 \\
\hline Finland & 192685,3 & 16992,7 & 0,80 & 8,8 & $-0,5$ & 0,2 & 0,6 \\
\hline Netherlands & 385559,6 & 361792,7 & 12,47 & 93,8 & 0,2 & 2,5 & 66,0 \\
\hline Spain & 171344,4 & 52209,0 & 5,15 & 30,5 & 0,2 & 0,8 & 17,0 \\
\hline Poland & 51347,7 & 18471,6 & 6,85 & 36,0 & 0,2 & 0,9 & 3,2 \\
\hline Germany & 191322,7 & 61569,9 & 2,44 & 32,2 & $-0,1$ & 0,8 & 26,9 \\
\hline Italy & 159537,9 & 39972,2 & 3,04 & 25,1 & 0,0 & 0,7 & 13,8 \\
\hline Croatia & 52071,9 & 14088,0 & 4,28 & 27,1 & $-0,2$ & 0,7 & 0,2 \\
\hline Czech Republic & 103686,9 & 36005,2 & 4,09 & 34,7 & 0,0 & 0,9 & 1,6 \\
\hline Sweden & 315696,1 & 91437,4 & 2,16 & 29,0 & $-0,2$ & 0,8 & 5,6 \\
\hline France & 210692,9 & 55312,7 & 2,86 & 26,3 & 0,1 & 0,7 & 23,8 \\
\hline
\end{tabular}

Source: calculated by the author according to the State Statistics Service of Ukraine, Eurostat, and preliminary data by market experts

Table 8

Indicators of relative advantages in mutual trade between Ukraine and the countries of the world by commodity groups of agro-industrial complex in 2010-2020

\begin{tabular}{|c|c|c|c|c|c|c|c|c|c|c|c|c|c|c|}
\hline \multirow{2}{*}{$\begin{array}{c}\text { Section, } \\
\text { product } \\
\text { group } \\
\text { UKTZED }\end{array}$} & \multicolumn{2}{|c|}{ Europe } & \multicolumn{2}{|c|}{ CIS } & \multicolumn{2}{|c|}{ Asia } & \multicolumn{2}{|c|}{ America } & \multicolumn{2}{|c|}{ Africa } & \multicolumn{2}{|c|}{$\begin{array}{c}\text { Australia and } \\
\text { Oceania }\end{array}$} & \multicolumn{2}{|c|}{$\begin{array}{l}\text { Other unspecified } \\
\text { countries }\end{array}$} \\
\hline & 2010 & 2020 & 2010 & 2020 & 2010 & 2020 & 2010 & 2020 & 2010 & 2020 & 2010 & 2020 & 2010 & 2020 \\
\hline 01 & $-6,3$ & $-3,6$ & 3,5 & 6,5 & $-0,5$ & 4,8 & $-0,7$ & $-0,8$ & & 3,7 & & & & \\
\hline 02 & $-6,6$ & 0,1 & 5,3 & 5,0 & 1,1 & 6,6 & $-6,5$ & $-1,9$ & & 4,5 & 0,3 & $-3,3$ & & $-3,3$ \\
\hline 03 & $-4,9$ & $-2,5$ & $-0,2$ & 1,0 & $-3,9$ & $-1,7$ & $-2,3$ & $-4,3$ & $-8,8$ & $-8,3$ & $-4,6$ & $-5,9$ & & $-5,9$ \\
\hline 04 & $-1,9$ & $-0,4$ & 2,6 & 2,2 & & 6,3 & $-1,0$ & 7,6 & & & $-0,8$ & $-5,2$ & & $-5,2$ \\
\hline 05 & 0,5 & 0,6 & 1,5 & 4,0 & 1,6 & $-0,4$ & & $-2,8$ & & & & & $-5,9$ & \\
\hline 06 & $-6,4$ & $-2,7$ & 1,9 & 3,2 & $-3,9$ & 0,0 & & $-5,3$ & & & & 0,2 & & 0,2 \\
\hline 07 & $-0,5$ & 0,1 & 3,0 & $-1,2$ & $-0,9$ & $-0,6$ & $-2,0$ & $-0,2$ & $-0,9$ & $-0,8$ & 3,3 & 3,2 & & 3,2 \\
\hline 08 & $-0,6$ & 0,7 & 1,6 & $-0,3$ & $-1,2$ & $-2,4$ & $-7,5$ & $-4,2$ & $-5,5$ & $-6,4$ & $-0,6$ & $-4,4$ & & $-4,4$ \\
\hline 09 & $-2,4$ & $-3,1$ & $-2,2$ & 1,3 & $-4,0$ & $-2,8$ & $-3,5$ & $-3,4$ & $-3,8$ & $-6,8$ & $-1,7$ & $-0,7$ & & $-0,7$ \\
\hline 10 & 1,1 & 3,1 & 3,0 & 0,5 & 4,0 & 4,8 & $-8,0$ & 2,3 & & 15,1 & $-3,0$ & $-0,3$ & & $-0,3$ \\
\hline 11 & $-0,5$ & 0,7 & 1,6 & 0,3 & 3,9 & 4,4 & 0,9 & 4,1 & 1,7 & 3,6 & & $-1,9$ & & $-1,9$ \\
\hline 12 & 2,5 & 2,5 & 3,8 & 3,5 & 2,2 & 1,4 & $-1,0$ & $-3,0$ & 2,0 & 1,1 & $-5,3$ & $-4,0$ & & $-4,0$ \\
\hline 13 & $-4,8$ & $-3,6$ & 2,1 & 0,1 & $-6,4$ & $-4,2$ & $-4,8$ & $-3,5$ & & & & & & \\
\hline 14 & & 7,0 & 2,8 & 2,7 & & 1,5 & & 3,2 & & & 2,2 & & & \\
\hline 15 & 2,2 & 3,5 & 3,3 & 3,8 & 1,3 & 2,9 & 0,6 & 4,3 & 8,3 & 4,8 & & 8,6 & & 8,6 \\
\hline 16 & $-3,3$ & $-2,4$ & 0,5 & $-0,2$ & $-2,7$ & $-1,6$ & $-2,5$ & $-2,4$ & 3,2 & $-1,6$ & 1,6 & $-0,5$ & & $-0,5$ \\
\hline 17 & 0,4 & 0,9 & 1,1 & 3,9 & 1,4 & 1,1 & $-4,6$ & 2,0 & 0,7 & 2,3 & & $-1,4$ & & $-1,4$ \\
\hline 18 & $-1,1$ & $-0,8$ & 2,3 & 2,9 & 1,0 & $-0,1$ & 3,4 & 1,8 & $-14,3$ & $-6,1$ & 4,1 & & & \\
\hline 19 & $-1,3$ & $-0,3$ & 1,8 & 3,4 & 2,8 & 1,1 & 2,2 & 4,2 & 2,9 & 1,8 & 0,8 & $-1,3$ & & $-1,3$ \\
\hline 20 & $-0,9$ & 0,2 & 2,6 & 1,4 & $-2,7$ & $-1,0$ & $-2,5$ & 0,7 & $-2,0$ & $-4,8$ & 6,7 & 0,2 & & 0,2 \\
\hline 21 & $-2,6$ & $-1,5$ & 0,5 & 2,3 & $-0,7$ & $-0,7$ & $-4,0$ & $-2,3$ & 2,1 & 0,8 & & $-0,7$ & & $-0,7$ \\
\hline 22 & $-1,0$ & $-1,5$ & 2,0 & 1,2 & $-0,8$ & $-0,5$ & $-0,7$ & $-0,9$ & $-0,8$ & $-0,7$ & 0,4 & $-3,3$ & & $-3,3$ \\
\hline 23 & 0,5 & 1,0 & 1,7 & 5,5 & 3,3 & 3,6 & & $-3,8$ & & 1,8 & & $-1,4$ & & $-1,4$ \\
\hline 24 & $-5,3$ & $-3,5$ & 0,3 & 2,4 & 0,0 & 1,5 & $-4,4$ & $-1,5$ & & $-1,7$ & & & & \\
\hline
\end{tabular}

Source: calculated by the author according to the State Statistics Service of Ukraine 
Table 9

Priority commodity groups of Ukraine's exports for sale in the world markets by the criterion of relative advantages in $\mathbf{2 0 2 0}$

\begin{tabular}{|c|c|c|c|c|c|c|c|c|c|c|c|c|c|}
\hline \multicolumn{2}{|c|}{ Europe } & \multicolumn{2}{|c|}{ CIS } & \multicolumn{2}{|c|}{ Asia } & \multicolumn{2}{|c|}{ America } & \multicolumn{2}{|c|}{ Africa } & \multicolumn{2}{|c|}{$\begin{array}{c}\text { Australia and } \\
\text { Oceania }\end{array}$} & \multicolumn{2}{|c|}{$\begin{array}{c}\text { Other unspecified } \\
\text { countries }\end{array}$} \\
\hline 率量 & 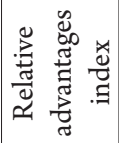 & 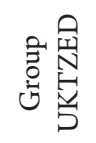 & 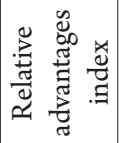 & 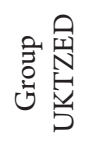 & 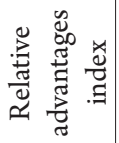 & 害望 & 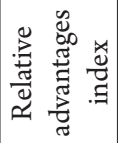 & 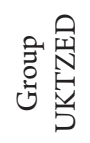 & 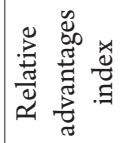 & 言望 & 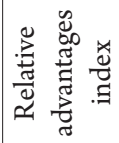 & 言畋 & 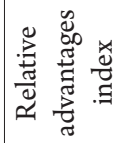 \\
\hline \multicolumn{14}{|c|}{ Currently sold in the region and have high advantages } \\
\hline 10 & 3,1 & 01 & 6,5 & 01 & 4,8 & 04 & 7,6 & 02 & 4,5 & 15 & 8,6 & & \\
\hline 12 & 2,5 & 02 & 5,0 & 02 & 6,6 & 10 & 2,3 & 10 & 15,1 & & & & \\
\hline 14 & 7,0 & 04 & 2,2 & 10 & 4,8 & 11 & 4,1 & 15 & 4,8 & & & & \\
\hline 15 & 3,5 & 05 & 4,0 & 11 & 4,4 & 15 & 4,3 & 23 & 1,8 & & & & \\
\hline \multirow[t]{12}{*}{23} & 1,0 & 06 & 3,2 & 12 & 1,4 & 15 & 4,3 & & & & & & \\
\hline & & 09 & 1,3 & 15 & 2,9 & 18 & 1,8 & & & & & & \\
\hline & & 12 & 3,5 & 23 & 3,6 & 19 & 4,2 & & & & & & \\
\hline & & 15 & 3,8 & & & & & & & & & & \\
\hline & & 17 & 3,9 & & & & & & & & & & \\
\hline & & 18 & 2,9 & & & & & & & & & & \\
\hline & & 19 & 3,4 & & & & & & & & & & \\
\hline & & 20 & 1,4 & & & & & & & & & & \\
\hline & & 21 & 2,3 & & & & & & & & & & \\
\hline & & 22 & 1,2 & & & & & & & & & & \\
\hline & & 23 & 5,5 & & & & & & & & & & \\
\hline & & 24 & 2,4 & & & & & & & & & & \\
\hline \multicolumn{14}{|c|}{ Currently poorly represented in the market of the region, but have advantages and prospects for development } \\
\hline 02 & 0,1 & 03 & 1,0 & 14 & 1,5 & 14 & 3,2 & 01 & 3,7 & 06 & 0,2 & 02 & 4,3 \\
\hline 05 & 0,6 & 10 & 0,5 & 17 & 1,1 & 17 & 2,0 & 11 & 3,6 & 07 & 3,2 & 04 & 1,6 \\
\hline 07 & 0,1 & 11 & 0,3 & 19 & 1,1 & 20 & 0,7 & 12 & 1,1 & 20 & 0,2 & 10 & 1,2 \\
\hline 08 & 0,7 & 13 & 0,1 & 24 & 1,5 & & & 17 & 2,3 & & & 12 & 2,0 \\
\hline 11 & 0,7 & 14 & 2,7 & & & & & 19 & 1,8 & & & 13 & 0,5 \\
\hline 17 & 0,9 & & & & & & & 21 & 0,8 & & & 14 & 0,3 \\
\hline \multirow[t]{4}{*}{20} & 0,2 & & & & & & & & & & & 15 & 0,4 \\
\hline & & & & & & & & & & & & 16 & 0,5 \\
\hline & & & & & & & & & & & & 17 & 0,8 \\
\hline & & & & & & & & & & & & 18 & 0,3 \\
\hline \multicolumn{14}{|c|}{ Currently sold on the market, but has no advantages } \\
\hline 01 & $-3,6$ & 16 & $-0,2$ & 03 & $-1,7$ & 01 & $-0,8$ & 03 & $-8,3$ & 01 & & 06 & $-1,1$ \\
\hline 03 & $-2,5$ & 07 & $-1,2$ & 05 & $-0,4$ & 02 & $-1,9$ & 04 & & 02 & $-3,3$ & 07 & $-0,1$ \\
\hline 04 & $-0,4$ & 08 & $-0,3$ & 06 & 0,0 & 03 & $-4,3$ & 05 & & 03 & $-5,9$ & 08 & \\
\hline 06 & $-2,7$ & & & 07 & $-0,6$ & 05 & $-2,8$ & 06 & & 04 & $-5,2$ & 09 & \\
\hline 09 & $-3,1$ & & & 08 & $-2,4$ & 06 & $-5,3$ & 07 & $-0,8$ & 05 & & 11 & \\
\hline 13 & $-3,6$ & & & 09 & $-2,8$ & 07 & $-0,2$ & 08 & $-6,4$ & 08 & $-4,4$ & 19 & $-0,2$ \\
\hline 16 & $-2,4$ & & & 13 & $-4,2$ & 08 & $-4,2$ & 09 & $-6,8$ & 09 & $-0,7$ & 20 & $-0,2$ \\
\hline 18 & $-0,8$ & & & 16 & $-1,6$ & 09 & $-3,4$ & 13 & & 10 & $-0,3$ & 21 & \\
\hline 19 & $-0,3$ & & & 18 & $-0,1$ & 12 & $-3,0$ & 14 & & 11 & $-1,9$ & 22 & \\
\hline 21 & $-1,5$ & & & 20 & $-1,0$ & 13 & $-3,5$ & 16 & $-1,6$ & 12 & $-4,0$ & 23 & \\
\hline 22 & $-1,5$ & & & 21 & $-0,7$ & 16 & $-2,4$ & 18 & $-6,1$ & 13 & & 24 & \\
\hline \multirow[t]{9}{*}{24} & $-3,5$ & & & 22 & $-0,5$ & 21 & $-2,3$ & 20 & $-4,8$ & 14 & & & \\
\hline & & & & & & 22 & $-0,9$ & 22 & $-0,7$ & 16 & $-0,5$ & & \\
\hline & & & & & & 23 & $-3,8$ & 24 & $-1,7$ & 17 & $-1,4$ & & \\
\hline & & & & & & 24 & $-1,5$ & & & 18 & & & \\
\hline & & & & & & & & & & 19 & $-1,3$ & & \\
\hline & & & & & & & & & & 21 & $-0,7$ & & \\
\hline & & & & & & & & & & 22 & $-3,3$ & & \\
\hline & & & & & & & & & & 23 & $-1,4$ & & \\
\hline & & & & & & & & & & 24 & & & \\
\hline
\end{tabular}

Source: calculated by the author according to the State Statistics Service of Ukraine 
unilateral foreign trade operations or the absence of foreign trade in these goods.

In general (with the exception of the CIS market), in recent years, the list of domestic export groups that had sustainable relative advantages in mutual trade with the world (the indices of relative advantages are greater than one and positive) is small, and all of these groups are low-tech exports. Ukrainian agricultural exports to Australia and Oceania are extremely underdeveloped.

However, there is a potential opportunity to increase exports of Ukrainian products with a greater degree of technological processing, in particular, to the markets of European countries - products of the flour-andcereal industry, sugar and confectionery products from it; to the markets of Asia - finished grain products; tobacco and its industrial substitutes; America - sugar and confectionery products; vegetable processing products; Africa - products of the flour-and-cereal industry; sugar and confectionery products from it; finished grain products.

\section{Conclusions}

The formation of export potential of Ukrainian agro-industrial complex is influenced by both positive and negative restraining factors. The results of the analysis for 2010-2020 indicate the following trends: high dynamism of foreign trade in agri-food products in Ukraine and annual increase in the total trade surplus; the main markets for domestic agricultural products are Asia, Europe and Africa, while imports from the CIS, a major partner in the past, are declining; under conditions of aggravation of the world food problem, despite the crisis related to COVID-19, there is a significant increase in global demand for agricultural products, especially finished food, and the structure of Ukrainian exports is dominated by commodity groups of low-tech raw materials, which steadily occupy the leading position in the world market; halving the share of finished food products in the overall structure of Ukraine's agricultural exports and the rapid deterioration of the foreign trade balance due to a decrease in their exports and an increase in imports; weakness of Ukrainian agro-industrial complex is due to the priority of strengthening the export potential of agricultural products (commodity groups and semi-finished products), as evidenced by the low level of export efficiency, despite the significant activity of Ukraine in the world agricultural market compared to major foreign trade partners; low technological formation of the export potential of the agroindustrial complex of Ukraine compared to the EU countries, which is manifested in low export efficiency; a limited list of commodity groups of Ukrainian exports with stable relative advantages and their low-tech in relation to countries of all regions of the world, except the CIS market, where high comparative advantages in finished food products are observed. Undeveloped export of Ukrainian products to the markets of Australia and Oceania. Thus, the lack of structural reforms in the agro-industrial complex of Ukraine can lead to irreversible lagging behind the main direction in the globalized world - the production and export of food products with high added value.

The approach proposed by the authors to the assessment of the export potential of the agro-industrial complex can become a methodological basis for expert assessment when justifying and improving national strategies for the development of countries' export activities.

The prospects for further research in this area are the analysis and evaluation of the factors of transition of Ukrainian agro-industrial complex from a raw material model of development to a model focused on the creation of added value within the country, in particular, the study of the degree and characteristics of the involvement of Ukrainian agricultural producers in global value chains and the justification of directions and mechanisms to solve geo-economic problems of export potential of the agricultural sector in the context of increasing its international competitiveness.

\section{References:}

Bosak, A. O. (2019). Potochnyi stan ta perspektyvy rozvytku APK Ukrainy: poshuk novykh rynkiv zbutu [Current state and prospects of development of agro-industrial complex of Ukraine: search of new markets]. Naukovyi visnyk Uzhhorodskoho natsionalnoho universytetu [Scientific Bulletin of Uzhhorod National University], 24(1). (in Ukrainian)

Budziak, V., \& Budziak, O. (2020). Zernovyj eksport Ukrayny [Grain exports of Ukraine]. Zovnishnja torghivlja: ekonomika, finansy, pravo [Foreign trade: economics, finance, law], 4. (in Ukrainian)

Cabinet of Ministers of Ukraine (2013). Pro skhvalennja Koncepciji rozvytku derzhavno-pryvatnogho partnerstva $v$ Ukrajini na 2013-2018 roky: Rozporjadzhennja Kabinetu Ministriv Ukrajiny; Koncepcija vid 14.08.2013 № 739-r [On approval of the Concept for the development of public-private partnership in Ukraine for 2013-2018: Order of the Cabinet of Ministers of Ukraine; The concept of 14.08.2013 № 739-r]. (in Ukrainian)

Cabinet of Ministers of Ukraine (2013). Pro skhvalennja Strateghiji rozvytku aghrarnogho sektoru ekonomiky na period do 2020 roku: Rozporjadzhennja Kabinetu Ministriv Ukrajiny; Strateghija vid 17.10.2013 № 806-r [On approval of the Strategy for the development of the agricultural sector of the economy for the period up to 2020: Order of the Cabinet of Ministers of Ukraine; Strategy from 17.10.2013 № 806-r]. (in Ukrainian) 
Cabinet of Ministers of Ukraine (2007). Pro zatverdzhennja Derzhavnoji ciljovoji proghramy rozvytku ukrajinsjkogho sela na period do 2015 roku: Postanova Kabinetu Ministriv Ukrajiny; Proghrama, Pasport, Zakhody vid 19.09.2007 №1158 [About the statement of the State target program of development of the Ukrainian village for the period till 2015: the Resolution of the Cabinet of Ministers of Ukraine; Program, Passport, Activities from 19.09.2007 № 1158]. (in Ukrainian)

Chesnik, N. M., Rozhko, Z. P., \& Strus, L. A. (2019). Eksportno-importnyi potentsial molochnoi promyslovosti Ukrainy [Export-import potential of the dairy industry of Ukraine]. Derzhava ta rehiony [State and regions], 3, 147-155. (in Ukrainian)

Dukhnytskyi, B. V. (2019). Rozvytok i perspektyvy ahrarnoho eksportu Ukrainy [Development and prospects of agricultural exports of Ukraine]. Visnyk ahrarnoji nauky [Bulletin of Agricultural Science], 5(794). (in Ukrainian) European Statistical Office (Eurostat) (2021). Available at: https://ec.europa.eu/eurostat/data/database?node_ code $=$ aact eaa01 (accessed 05 November 2021).

FAO (2020). Electronic resources. Available at: http://www.fao.org/faostat/en/\#data/TI (accessed 15 June 2021). (in English)

Golovachova, O. S., Iksarova, N. O., \& Kudyrko, L. P. (2018). Prospects for increasing exports of agricultural products in the context of deepening the strategic partnership between Ukraine and the EU. Scientific bulletin of Polissia, 1(13), 1. (in English)

Herajmovych, V. L., Humenjuk, I. L., \& Kubaj, O. G. (2019). Suchasnyi stan rozvytku haluzi ta eksportu produktsii tvarynnytstva Ukrainy [The current state of development of the industry and export of livestock products of Ukraine]. Ekonomika. Finansy. Menedzhment: aktualni pytannia nauky i praktyky [Economy. Finances. Management: current issues of science and practice], 5, 36-45. (in Ukrainian)

Izhevskyi, P. G. (2018). Aghropromyslovyj kompleks Ukrajiny: suchasnyj stan, tendenciji ta perspektyvy rozvytku [Agro-industrial complex of Ukraine: current state, trends and prospects of development]. Intelekt XXI [Intelligence XXI], 3. (in Ukrainian)

Ladychenko, K. I., \& Tunitska, Yu. M. (2019). Features of trade facilitation in Ukraine in the context of sustainable development strategy. Strategic Management: Global Trends and National Peculiarities (Collective monograph). Poland: Baltija Publishing.

Lazarjeva, O. V., \& Vakar, K. V. (2019). Rozvytok eksportnogho potencialu aghrarnogho sektora ekonomiky Ukrajiny v umovakh ghlobalizaciji [Development of export potential of the agricultural sector of Ukraine's economy in the conditions of globalization]. Aghrosvit [Agrosvit], 1-2, 3-9. (in Ukrainian)

Lyakhovska, O. V. (2019). Tendenciji eksportu zerna i produktiv jogho pererobky v Ukrajini [Trends in exports of grain and products of its processing in Ukraine]. Derzhava ta reghiony [State and regions], 5, 44-48. (in Ukrainian)

Ministry of Economy of Ukraine (2019). Sektoraljna eksportna strateghija "Kharchova i pererobna promyslovistj Ukrajiny na 2019-2023 rr." [Sectoral export strategy "Food and processing industry of Ukraine for 2019-2023"]. Available at: https://www.me.gov.ua/Documents/Detail?lang=uk-UA\&id=515d8680-59af-417d-b782-ebbe388f 3dd3\&title=SektoralnaEksportnaStrategiiakharchovaIPererobnaPromi slovistUkraini-doslidzhennia-Ukrainskoiu Movoiu (accessed 15 June 2021). (in Ukrainian)

Melnyk, T. M., \& Tunitska, Yu. M. (2020). Instytucijne zabezpechennja mizhnarodnoji konkurentospromozhnosti APK Ukrajiny [Institutional support of the international competitiveness of the agro-industrial complex of Ukraine]. Zovnishnja torghivlja: ekonomika, finansy, pravo [Foreign trade: economics, finance, law], 4(111), 69-90. (in Ukrainian)

Melnyk, Yu. V., \& Samosudov, A. S. (2020). Rozvytok eksportnogho potencialu pidpryjemstv molochnoji ghaluzi $\mathrm{v}$ umovakh jevropejsjkoji integhraciji Ukrajiny [Development of export potential of dairy enterprises in the conditions of European integration of Ukraine]. Molodyj vchenyj [Young Scientist], 3(79), March. (in Ukrainian)

Nadvynychnyj, S. A. (2018). Suchasni umovy formuvannja ta realizaciji eksportnogho potencialu aghrarnoji sfery reghioniv Ukrajiny [Modern conditions of formation and realization of export potential of agrarian sphere of regions of Ukraine]. Ekonomichnyj analiz [Economic analysis], 28(3), 56-61. (in Ukrainian)

Okhrimenko, O. O. (2018). Integhrovanyj rozvytok eksportnogho potencialu APK Ukrajiny v konteksti transformaciji zovnishnjoekonomichnykh zv'jazkiv [Integrated development of the export potential of the agroindustrial complex of Ukraine in the context of the transformation of foreign economic relations]. Efektyvna ekonomika [Efficient economy], 4. (in Ukrainian)

Polkovnichenko, S. O., \& Rosokhach, O. V. (2016). Current trends in the realization of the export potential of the agricultural sector of the economy of Ukraine. Naukovyj visnyk Polissja [Scientific Bulletin of Polissya], 1, 37-45.

Popko, O. V. (2018). Eksportnyj potencial kharchovoji promyslovosti Ukrajiny [Export potential of the food industry of Ukraine]. Visnyk Nacionaljnogho universytetu vodnogho ghospodarstva ta pryrodokorystuvannja; Ekonomichni nauky [Bulletin of the National University of Water Management and Environmental Sciences: Economic sciences], 4, 154-165. (in Ukrainian)

State Service of Ukraine for Geodesy, Cartography and Cadastre (GeoCadastre) (n.d.). land.gov.ua. Available at: https://land.gov.ua/info/statystyka (in Ukrainian)

State Statistics Committee of Ukraine (2021). Available at: http://www.ukrstat.gov.ua/operativ/oper_new.html (accessed 27 October 2021). 
TrendEconomy (2021). Available at: https://trendeconomy.ru/data/commodity_h2/TOTAL (accessed 10 October 2021).

United Nations Statistics Division. UN Comtrade (2021). Available at: https://comtrade.un.org/data (accessed 22 October 2021).

Urba, S. I. (2019). Realizacija eksportnogho potencialu aghrarnogho sektoru v systemi zovnishnjoekonomichnoji bezpeky Ukrajiny [Realization of the export potential of the agricultural sector in the system of foreign economic security of Ukraine]. Infrastruktura rynku [Market infrastructure], 33, 116-124. (in Ukrainian)

Voronych, M. M. (2019). Rezuljtaty analitychnogho oghljadu aghrarnogho eksportu Ukrajiny [The results of the analytical review of agricultural exports of Ukraine]. Naukovi ghoryzonty [Scientific horizons], 11(84). (in Ukrainian)

World Bank (2020). Available at: https://databank.worldbank.org/indicator/NY.GDP.PCAP.CD/1ff4a498/ Popular-Indicators (accessed 20 June 2021).

Zrailo, I. I. (2019). Osoblyvosti strukturyzaciji eksportnogho potencialu zernoproduktovogho pidkompleksu APK [Features of structuring the export potential of the grain subcomplex of agro-industrial complex]. Visnyk Sumsjkogho nacionaljnogho aghrarnogho universytetu. Serija "Ekonomika i menedzhment" [Bulletin of Sumy National Agrarian University. "Economics and Management" series], 4(82). (in Ukrainian) 